\title{
Building of professional communicative competence in foreign students
}

\section{Desarrollo de competencias profesionales y comunicativas entre los estudiantes extranjeros}

\author{
Sevinc Karayel \\ Ardahan University, Ardahan, Turkey \\ ORCID ID: https://orcid.org/0000-0003-4542-5806 \\ Shalala Ramazanova \\ Ardahan University of Turkey (ARU University), Ardahan, Turkey \\ ORCID ID: https://orcid.org/0000-0002-3252-6504 \\ Olga Fisenko \\ Peoples' Friendship University of Russia (RUDN University), Moscow, Russian \\ Federation \\ ORCID ID: https://orcid.org/0000-0002-3824-5535
}

Received 07-07-20 Revised 09-25-20 Accepted 01-13-21 On line 01-25-21

*Correspondence

Email: olfiss@list.ru
Cite as:

Karayel, S., Ramazanova, S., \& Fisenko, O. (2021). Building of professional communicative competence in foreign students. Propósitos y Representaciones, 9 (SPE2), e943. Doi: http://dx.doi.org/10.20511/pyr2021.v9nSPE2.943 


\section{Summary}

The Turkish students who study at Russian universities continue learning Russian at the main departments. The main difficulty which foreign students face while learning Russian is scientific style. Those who teach Russian as a foreign language admit that foreign students are often unprepared to learn specific vocabulary. The article covers a completely different approach for presentation of specific vocabulary, developed by the authors of "Training for professional activity in Russian of "Public Relations" speciality foreign students" (L.V. Adonina, S.V. Lazarev, S.V. Smirnova, O.S. Fisenko).

Keywords: international students, Russian as a foreign language, communicative competence, foreign students.

\section{Resumen}

Los estudiantes turcos que están cursando sus estudios en las universidades rusas continúan aprendiendo el idioma ruso en sus respectivas facultades. Lo más complicado para ellos es dominar el lenguaje científico. Según la experiencia de los profesores de ruso como lengua extranjera, los estudiantes extranjeros no están lo suficientemente preparados como para asimilar el léxico especializado. El presente artículo versa sobre un enfoque totalmente nuevo de presentar el léxico científico elaborado por los autores del manual "Enseñanza de la actividad profesional en la lengua rusa a los estudiantes extranjeros que cursan estudios de Relaciones Públicas") (autores L.V. Adónina, S.V. Lásarev, S.V. Smirnova, O.S. Fisenko).

\section{Introduction}

The higher education reform in Russian Federation is aimed at the improvement of competitiveness, availability, sustainability, and globalization, as well as integration into the European educational space. The visible success has led to an increase in the number of foreigners, willing to study at Russian universities. Turkish students are not an exception there.

The main objective for the Turkish students who come to study at Russian universities is to learn Russian well enough for study at the main departments according to the chosen vocation and further integration into productive activities. Therefore, those who organize educational process (the university itself and professors) are to create completely new professional modules in different specialties, taking into account the vocational specificities of teaching Russian as foreign language.

\section{Formulation of the problem}

One of the most popular specialties among the Turkish students, who enter Russian universities, is Public Relations (PR).

The vocational training of a future PR specialist is a complex multi-level process during which they acquire systematized special and professional communicative skills and expertise and, thus, use them in practice. Those professors who teach Russian as a foreign language and supervisors are to develop new professional modules in terms of Russian as a foreign vocationrelated language.

Such a completely different approach for presentation of specific vocabulary has been developed by the authors of "Training for professional activity in Russian of "Public Relations" speciality foreign students".

The presentation system is based in a way that provides foreign students' comprehension of complicated scientific texts.

The developed didactic system meets the requirements of "State Educational Standard for Russian as a foreign language. Second level. General language proficiency» (Ivanova, T.A. et al., Moscow, Saint Petersburg, Zlatoust, 1999) and "Federal State Educational Standard for "Advertising and public relations" (bachelor's level) (August 2016)". 


\section{Problem Discussion}

\section{Characteristics of a PR specialist's professional activity}

Public relations is a kind of professional activity that deals with communication and management relations sphere. As a profession, PR is based on the acknowledging the openness of social information, mutually beneficial cooperation between controlling agents and the public, as well as reliance upon public opinion. Hence, information transmission and exchange, along with decision-making, play a vital role in a PR specialist's professional activity, determining their relationships with others.

The built professional communicative competence allows PR specialists to apply different communication techniques for improving managers' image, building relationships with different social groups, managing crises inside and outside a company.

As an activity, public relations is aimed at solving the problems related to creating favorable conditions for interrelations with social environment. That is why the vocational training of PR specialists is of particular importance in the terms of professional activity.

\section{Vocational training of PR specialists}

Professional communicative competence is built during vocational training where students acquire knowledge related to their vocation.

The vocational training of PR specialists is a complex multi-level process that has several stages: acquiring expertise and skills, developing interest to work and its results, comprehending methods (Klimov, 1988, p. 131). Each stage is a crucial, formative element.

From the first year at university students are involved into the educational process that provides building professionally important competence.

The foreign students who prepare for a career of PR specialist learn vocation-related language in the context of scientific style from the beginning of their study. One of the modern textbooks for those who study Russian as a foreign language is "Training for professional activity in Russian of "Public Relations" speciality foreign students" (L.V. Adonina, S.V. Lazarev, S.V. Smirnova, O.S. Fisenko). The textbook contains a system of exercises developed by the authors, which provide building of professional communicative competence in foreign students.

During the educational process future specialists improve their personality, becoming more creative, active and socially mature. «Thus, the concept of educational training is substituted for the concept of training education. The concept of training education means that the results of the activity of a university are characterized by the level of ethics and social maturity the students demonstrate in their life and future career, the pattern and the specifics of their needs and motivation, the dynamics of mental development, the development of individual and cognitive abilities» (Kasatkina, 2002, p. 83). Teaching Russian as a foreign language leads to the need for practical use. Speaking of teaching foreign students, forming a secondary linguistic personality, ready for vocational training at university, is of great importance there.

Practical experience of building a professional communicative competence in foreign students, based on the example of vocational training of PR specialists

Let us demonstrate the fragment of a "PR campaigns" lesson as the example of building a communicative competence in foreign PR students.

Building of professional communicative competence begins with the identification of the competencies, important for a PR specialist. For instance, one of the competencies, important for a PR specialist, is the skill of PR campaigning. 
Teaching the vocation-related language at the PR Department is considered as the acquisition of expertise, professional skills and competences, as well as their practical usage, the vocation-related language plays a crucial role there.

The exercises are structured specifically to make foreign students reflect on their vocation and experience social and intercultural perception.

The tasks after the texts in the exercises make foreign students prepared for interpersonal and informational perception. Before reading a text, the students do the following exercises.

Task 1. Read the words, memorize their meaning, placement and use.

Stimulate what? (sales) - activate something

Stimulate what? (trade) - activate something

Contribute to something? (to buyers) in what? (in the purchase of goods) - to provide assistance, facilitate really is

Exaggerate / exaggerate what? (difficulties, problems) - imagine more than it

Exaggeration of what? (difficulties)

Implement / implement what? (idea, image in the buyer's mind) - introduce, strengthen into something

Implementation of what? (ideas)

Task 2. Form adjectives from nouns using the suffixes -onn / -enn; -ov / -ev; -icc; -n.

a) information

the television

constitution

organization

state

trade

society

a life

time

b) goal

a business

speech

right

weight

price

a game

c) strategy

capitalist

theory

socialist

d) goods

advertising

morality

plot

audience

news

Задание 3. Прочитайте и объясните, как вы понимаете следующие выражения. 
Стимулирование продаж товаров и услуг, реклама воздействует на покупателя, реклама способствует действиям по приобретению товаров и услуг, увеличение продаж продукции, высказывания выглядят преувеличением, образ внедряется в сознание покупателя

Activity 3. Read and explain your understanding of the following expressions.

Stimulating sales of goods and services, advertising affects the buyer, advertising promotes actions to purchase goods and services, increase product sales, statements look exaggerated, the image is introduced into the mind of the buyer

Task 4. What are the antonyms for verbs and adjectives in these phrases.

Increase impact, improve the situation, positive image, wide choice, sophisticated methods, raise prices, good offer, specific idea.

Task 5. Find a common root in the following words.

one). To propose, proposal, proposing, stated, presentation, setting out, suggest.

2). Enlarge, great, magnitude, greatness, increase, majestic.

3). Affirm, affirm, assert, assert, confirm, attest, firm, firm.

4). Pick, elect, voter, collect, gather, pick, pick, pick, pick.

As we can see, the system of methodical exercises has been developed exactly to combine methodical objectives related to improving language skills and professional communicative competence in the educational process.

The exercises are focused on the vocational training to enhance the effectiveness of professional activity. Cognitive obstacles affect the comprehension (searching the right answer) and expression (use of adequate linguistic means).

The comprehension of scientific language allows foreign students to apply their knowledge in the educational process.

Teaching the vocation-related language enhance an individual's cognitive abilities, providing the improved mental processing of scientific texts. «For example, a student must be able to abstract the central message, make a precis, and orientate themselves in different texts... The student identifies the advantages of learning different types of text-processing at the foreign language lessons» (Vitt, 1973, p. 33).

The next stage of building of professional communicative competence is reading a scientific non-adapted text. Let us give the following text as the example: "Information and communication technologies for advertising and PR-campaigns."

\section{Information and communication technologies in conducting advertising and pr-companies}

In different approaches, spheres of activity, there are very different definitions of the concept of "advertising". However, from a practical point of view, the main goal and purpose of commercial advertising is to stimulate now and / or in the future sales of certain goods or services. To do this, advertising affects the buyer and promotes his actions to purchase the advertised goods and services. At the same time, a number of different methods and techniques are used that affect various mental structures of a person, both at the conscious and unconscious levels. To designate these methods and techniques, the concept of "advertising impact" is used. 
For definiteness, we will talk about advertised goods, at the same time implying both goods and services, mainly focusing on commercial advertising, however, many of the methods described below are used, with appropriate changes, in the field of noncommercial advertising. Much similar methods are used in political advertising, however, the main emphasis in the presentation of examples will be on television commercials, since they usually use a wide range of different advertising techniques.

As mentioned above, the main strategic goal of advertising is to increase sales of a company's products. There is also no doubt that the consumer is aware of both this task and the various advertising methods. In this regard, some of these methods seem to be quite complex, and some are explicit and simple. We will single out "affirmative statements" and "selective selection of information" as such obvious, but still separate methods of advertising.

- The first method is called Affirmative Statements.

The method consists in using statements that are presented as fact, with the implication that these statements are self-evident and do not require proof. Almost all advertising is based on this method.

Moreover, quite often these statements from a rational point of view and in isolation from advertising look like a certain exaggeration, for example, such slogans as: "It's not for nothing that all children love Huggies" (advertising for Huggies diapers) or "New Year is twice as tasty if you MilkyWay "(advertisement of" MilkyWay "chocolate).

- The second method is called "Selective selection of information".

The essence of the method consists in a special selection and use of only those facts that are beneficial for the information and psychological impact of advertising.

It is interesting that the practice of using a similar method is found in political struggle, management of socio-political processes, and election campaigns.

However, in the case of advertising, in most cases, the consumer has no doubts about using both the "Selective selection of information" method and the "Affirmative statements" method. As a result, the isolated use of these methods in advertising without implementing others does not lead to significant impact on the consumer, however, their absence can lead to a decrease in the impact of advertising.

- The third method is called "Using Slogans".

The main idea of this method is to use a variety of slogans, mottos and slogans. This allows you to "concentrate" the main features, name and / or image of the advertised product in one phrase, which is introduced into the mind of the consumer. Another feature of the method is that when using the slogan, not only and not so much the features of a particular product are remembered, but its idealized and positive image. For example, instead of the brands "Aquafresh", "Synergy S", "Ice-White", the slogans "Triple protection for the whole family", "To make the skin shine with health", "To preserve the whiteness of teeth" are used.

When using slogans, it is especially important to create a clear association between the brand and the slogan itself, for which it often includes the name of the brand or company: "Blend-a-ted - let your smile shine with health", "Fun and tasty McDonalds "," Roventa Delta - conquers at first sight ", etc. To improve the perception and memorability of slogans, advertising uses bright and short phrases, rhyme. For example: "Cleanliness is purely tide", "Mezim is indispensable for the stomach", "Appetite is playing up - don't slow down - Snickersney!", "Myth-machine is purely ideal and the price is real", etc.

\section{The fourth method is defined as "Contrast creation".}

A fairly common advertising method is the "contrast creation" method. The main task here is to show the advertised product as something different from the rest, radically improving the situation, having exceptional properties, efficiency, etc. The main emphasis is on emotions. For this, a wide arsenal of methods is used for 
constructing video sequences of advertising plots, speeches and comments, creating special game and plot situations.

For example, an advertisement for the Pepsi drink uses black and white photography of the streets and a color image of the Parsi trademark, while the advertisement for Sosa-Co1a uses an illuminated road train with the inscription A1ways Sosa-Co1a, which, driving through a dark forest and the city, spreads light around itself and makes lights come on.

At this stage building the skills of reading and retelling scientific texts is of great importance. The speech skills and the ability to use complex linguistic structures are developed there. The skills of text-compressing, text-expanding, content-changing, adding personal opinion after the retelling is also crucial.

Let us review some exercises.

Task 6. Make sentences and use constructions in them what is (is) what; what is (is) that; what is (is) that.

one). The goal of politics in a democratic society is to build a harmonious society.

2). The appointment of the PR for politics is to increase the electorate of this or that politician.

3). In industry, public relations has two challenges. The first is to establish contacts with 3 social groups: customers, shareholders, employees. The second task is to promote the company's services and products in a highly competitive environment.

4). The essence of PR activities is establishing and maintaining contacts, influencing public opinion.

5). The essence of the PR-specialist's work is to achieve mutual understanding between people.

6). The goal of the PR-activity system in a democratic society is to make the interests of civil society the basis of public relations.

7). The success of most electoral campaigns is the use of political advertising and propaganda methods.

8). PR-company planning - analysis and calculation of the possibilities of using different PR-technologies.

nine). The task of the PR-specialist in the field of economics is to keep in touch with competitors, advertise and promote products on the market.

ten). It is the duty of the PR specialist in the field of social relations to take care of the formation of goodwill between people.

eleven). The advantage of interviews over questionnaires is closer contact with the target audience.

Task 7. Complete the sentences:

one). The main purpose of commercial advertising is ...

2). Advertising affects the buyer and promotes ...

$3)$. Advertising affects the mental structures of a person as ...

4). The affirmative method consists of ...

5). The method of "selective selection of information" consists ...

$6)$. The slogan method consists of ...

Task 8. Replace the selected words and phrases with similar expressions from the text: 
one). Advertising influences the buyer and helps him choose the product to buy.

2 ). In this case, a number of different methods and techniques are used.

3). Apart from advertising, such statements look like hyperbole.

4). This method is useful for the informational impact of advertising.

$5)$. Using these methods separately from each other gives poor results.

6). This allows you to "collect" the main features in one phrase.

Task 9. Answer the questions.

one). What is the main purpose of advertising from a practical point of view?

2 ). Who does advertising affect and what does it contribute to?

$3)$. What term is used to refer to different methods of influencing the buyer?

4). Where else are the same methods used in advertising?

5). Does the consumer know about different advertising methods?

$6)$. What is the affirmative method?

7). What is the essence of the "selective selection of information" method?

8 ). What is the "use of slogans" method?

nine). What are the features of this method?

ten). What is the essence of the "create contrast" method?

Task 10. Form nominal combinations from verb phrases.

Influence the buyer -

Promote sales -

Use different methods and techniques -

Pick up different facts -

Remember the image -

Create contrast -

Show advertised product -

Improve the situation -

Task 11. Divide the text into semantic parts. Title each part in the form of noun sentences. Make a nominative outline of the text.

Task 12. Write down briefly the content of each semantic part of the text. Make abstracts of the text.

Task 13. On the basis of the nominative plan and theses, briefly tell the content of the text.

Task 14. Make a detailed record of the text. Write an outline of the text.

Task 15. Using the plan and outline, tell in detail about the techniques and methods of advertising.

The main tasks are aimed at self-reflection.

The following methods are used as methodological techniques: (1) determination of reading goals, choice of search orientations; (2) identification of semantic information blocks; (3) identification of information sources; (4) recording of extracted information; (5) compilation of a summary of the read information.

\section{Conclusiones}

The research leads to the following conclusions:

- building of professional communicative competence in the foreign students, who study at Russian universities, is the part of vocational training; 
- one of the most popular specialties among the Turkish students, who enter Russian universities, is Public Relations (PR);

- the vocation-related language plays a crucial role in the building of professional communicative competence. That is why the vocational training of PR specialists requires a highly structured didactic system;

- building of professional communicative competence in PR specialists depends on their level of skills related to the comprehension and processing of scientific text;

- learning specific vocabulary plays a significant role in the process of learning the vocation-related language;

- building of professional communicative competence is provided with practical communicative and illustrative methods of teaching. Derivational models help students realize and use derivational constructions in their speech. The educational process should be organized in an inductive way, from easy topics to more difficult ones to improve the skills of reading and comprehending scientific texts.

\section{References}

Adonina, L.V. \& Adonin, R.F. \& Fisenko, O.S. (2017) Cognitive trend in modern science of language: materials for the organization of academic work in classes of the philological profile. Language and Personality in a Multicultural Space. Digest of articles. Edited by I.N. Avdeeva, Russia, Moscow, 134-143

Adonina, L.V. \& Lazarev, S.V. \& Smirnova, S.V. \& Fisenko, O.S. (2017) Training for professional activity in Russian of "Public Relations" speciality foreign students. Ed.: Lazarev S.V. Russia, Moscow, 50

Fisenko O. \& Nikitina V. \& Bodrova T. (2019) Semantic-cognitive approach to the study of a language person in the system of human and individual values. Chile, Santiago, 106-112

Fisenko, O.S. (2015) The mental-linguistic space of the Russian religious and philosophical discourse of the late XIX - early XX centuries. Actual problems of science, education and social work. Collection of scientific articles. RGSU branch in Lyubertsy; Institute of Psychology, Sociology and Social Relations GAOU VO MGPU, Russia, Moscow, 194200

Kasatkina, N.E. (2002) Conceptual basics of university functioning as a regional educational center // Professional'noe obshchenie. Materialy rossiyskoy nauch.-prakt. Konf. (Kemerovo, 25-26 sent. 2001 g.) [Professional communication. Materials from Russian Research Practice Conference in Kemerovo (Kemerovo, September 25-26, 2001)]. Russia, Kemerovo, 82-89

Klimov, E.A. (1988) Introduction into the psychology of vocation. Russia, Moscow, 197

The 11 August 2016 Ministry of Education and Science Order 997 concerning approval of the Federal State Educational Standard in higher education with specialty 42.03.01 Advertising and Public Relations (bachelor level). - http:fgosvo.ru/news/5/1909

Vitt, N.V. (1973) The methods of teaching foreign languages at universities. Vol III. Part I. Russia, Moscow, 112

* This paper has been support by the RUDN University Strategic Academic Leadership Program. 